\title{
HEALTH INEQUALITIES BY EDUCATION, INCOME, AND WEALTH: \\ A COMPARISON OF 11 EUROPEAN COUNTRIES \\ AND THE US
}

Hendrik Jürges

$140-2007$

๑ $\boldsymbol{m e a - M a n n h e i m ~ R e s e a r c h ~ I n s t i t u t e ~ f o r ~ t h e ~ E c o n o m i c s ~ o f ~ A g i n g ~}$

L13, 17_D-68131 Mannheim_Phone +49 621 181-2773/1862_Fax +49 621 181-1863_www.mea.uni-mannheim.de 


\title{
Health inequalities by education, income, and wealth: a comparison of 11 European countries and the US
}

\author{
Hendrik Jürges \\ MEA, University of Mannheim \\ L13, 17 \\ 68131 Mannheim \\ Germany \\ Tel +49-621-181-3519 \\ Fax +49-621-181-1863 \\ Email: juerges@mea.uni-mannheim.de
}

December 2006

\begin{abstract}
I compare education-, income-, and wealth-related health inequality using data from 11 European countries and the US. The health distributions in the US, England and France are relatively unequal independent of the stratifying variable, while Switzerland or Austria always have relatively equal distributions. Some countries such as Italy dramatically change ranks depending on the stratifying variable.
\end{abstract}

Keywords: Socioeconomic inequality in health; concentration index; cross-country analysis

JEL-Codes: I12, I21, J14 


\section{Introduction}

Reducing health inequality is one of the main aims of any health care system, and health inequalities are regularly used to compare of health system performances (WHO, 2000). Combining data from HRS 2002, ELSA 2002 and SHARE 2004, I compare socio-economic inequalities in the physical health of the older population across 11 European countries and the US. The specific aim of this study is to examine how robust country rankings in terms of health inequality are with respect to the choice of the social stratification variable: education, current income, and wealth.

\section{Methods}

I use the concentration index as a measure of socio-economic health inequality (Kakwani et al., 1997). Let $y_{i}$ be a continuous health index, where higher values mean better health and $R_{i}$ the fractional education (or income or wealth) rank of individual $i$, then the concentration index $C$ is defined as

$$
C=\frac{2}{\bar{y}} \operatorname{Cov}\left(y_{i}, R_{i}\right)
$$

$C$ can be positive or negative, depending on whether inequalities favor individuals of higher or lower socio-economic status. $C$ is related to the Gini coefficient $G$, which measures "pure" health inequality. $G$ can be computed in the same way as $C$ with $R_{i}$ being the fractional health rank. $C$ is always smaller than the $G$ except when the health and the socio-economic rank are perfectly correlated.

When comparing $C$ across countries, one often wishes to control for differences in the demographic composition of the populations. The argument is that sex and age effects on 
health are partly biologically determined and thus outside the realm of health policy. I thus only report age-sex standardized concentration indices. I first estimate by OLS a linear regression of health

$$
y_{i}=\alpha+\beta \times S E S_{i}+\sum_{k=2}^{K} \gamma_{k} \times D_{k i}+\varepsilon_{i},
$$

where $S E S_{i}$ denotes the stratifying variable and $D_{k i}$ are Dummy-Variables for age-sex groups. Age-sex standardized ("avoidable") inequality $I^{*}$ is then computed as

$$
I^{*}=C-\frac{2}{\bar{y}} \sum_{k=2}^{K} \hat{\gamma}_{k} \operatorname{Cov}\left(D_{k i}, R_{i}\right)
$$

$I^{*}$ only deviates from $C$ if age and sex have a (partial) effect on health $\left(\hat{\gamma}_{k} \neq 0\right)$ and if age and sex are correlated with education $\left(\operatorname{Cov}\left(D_{k i}, R_{i}\right) \neq 0\right){ }^{1}$

In the following, I use sampling weights provided with my data to compute weighted concentration indices. Standard errors for $C$ and $I^{*}$ are then computed by bootstrap with 1000 repetitions.

\section{Data}

The US Health and Retirement Study (HRS), the English Longitudinal Study of Ageing (ELSA) and the Survey of Health, Ageing and Retirement in Europe (SHARE) are multidisciplinary surveys of the older population, containing comparable information on the health, income, and wealth of individuals aged 50 and over. $^{2}$ The countries participating in SHARE

\footnotetext{
${ }^{1}$ The method to compute $I^{*}$ is based on the decomposition formula suggested in Wagstaff et al. (2003).

${ }^{2}$ I use the 2002 wave extracted from the RAND HRS data file, which was developed at RAND with funding from the National Institute on Aging and the Social Security
} 
and the sizes of my working samples are shown in Table 1. In the following, I describe the measurement of the key variables.

<about here Table 1>

\subsection{Health}

Following Jürges (2007), I use a continuous physical health index which is based on a set of detailed "objective" health information, such as chronic conditions, functional, ADL and IADL limitations. This index ranges from 0 to 1 ; higher values represent better health. In this paper I use a set of 7 chronic conditions and 17 limitations to compute the index. The absence of any conditions or limitations implies an index value of 1 . The presence of a condition reduces the health index by some given percentage (the disability weight). Disability weights are computed from within the combined HRS, ELSA, and SHARE samples by estimating generalized ordered probit regressions of self-reported health on the set dummy variables indicating the presence of each of the conditions and limitations. The health index is equal to the linear prediction from this regression, normalized to the unit interval.

Administration. HRS, ELSA and SHARE are described by Juster and Suzman (1995), Marmot et al (2003), and Börsch-Supan et al. (2005), respectively. The youngest sampled HRS cohort in 2002 was born in 1947; individuals younger than 55 were thus excluded from the ELSA and SHARE samples, too. 


\subsection{Education, income, and wealth}

I use the ISCED-97 classification (OECD, 1999) of the highest degree as measure of education. The seven original education levels are recoded into four broader categories: "low" (pre-primary and primary education; ISCED 0 to 1), "medium" (lower secondary education; ISCED 2), "high" (upper secondary and post-secondary, non-tertiary education; ISCED 3 and 4), and "very high" (first and second stage of tertiary education; ISCED 5 and 6).

HRS, SHARE, and ELSA contain detailed information on income sources and assets on the individual and the household level. I use equivalent annual household income (mainly labor income, public pensions, and income from assets) in the preceding year as income measure. Household net worth is computed as the current value of all financial and real assets minus liabilities (and excluding pension wealth). As with income, I also use equivalent net worth as measure of wealth. Equivalent income and wealth levels are computed as household income and wealth divided by the square root of the number of persons in the household.

\section{Results}

Age-sex standardized Gini coefficients for pure health inequality and concentration indices for education-, income-, and wealth-related inequalities in health are shown in Table 2. Countries are listed in ascending order of pure health inequality. The Gini coefficients are in the range of 7 to 11 percent and significantly different from zero in all countries, i.e. health is unequally distributed everywhere. The order of countries in Table 2 also reflects a geographic pattern. At the bottom half of the table one finds Mediterranean countries (France, Spain, Italy, Greece) and Anglo-Saxon countries (US, England), while Nordic countries (Denmark, Sweden) and Western European countries (Netherlands, Germany, Austria, Switzerland) are 
at the top half. Pairwise t-tests show significant differences between the Gini coefficients of most country pairs. Exceptions are neighboring countries in terms of inequality: the Netherlands and Sweden, Denmark and Germany, and so on.

<about here Table 2>

Age-sex standardized concentration indices for socio-economic inequalities in health are almost always positive and statistically different from zero. The only exceptions are incomerelated inequalities in Austria and Switzerland. Thus, in all twelve countries, and independent of the stratification variable, inequalities in health favor individuals of higher socio-economic status. The all-country averages of the concentration indices are 1.6 percent for education, 1.1 percent for income, and 2.2 percent for wealth.

Table 3 summarizes the information in Table 2 in a different format. Countries are classified by whether estimated health inequalities are significantly smaller or larger than the allcountry average. This helps comparing country rankings based on different social stratification variables. A group of three countries (Netherlands, Sweden, and Switzerland) have lower than average pure health inequality, while a group of five (the Anglo-Saxon and Mediterranean countries except France) have higher than average pure inequalities.

The classification based on education-related inequalities is remarkably different: Germany is the only country with a smaller than average concentration index. In the large inequality group, there is less change. England, Italy, and the US remain in this group, and France joins this group. In fact, France is the country with the second largest education-related health inequality. Substantial changes to the classification are again found when one examines income-related inequalities in health. Italy, among the countries with the largest pure health 
inequality, is now in the group of countries with the smallest income-related inequality. The two countries with significantly larger than average income-related health inequality are again France and the US.

As a stratifying variable, household wealth might be preferable to education and current income. Current income only provides a snapshot view susceptible to transitory fluctuations (although for pensioners this is likely to be a smaller problem than for workers), whereas education is a rather crude indicator of life-time resources. In fact, wealth-related inequalities in health are larger than education- and income-related inequalities in all but two countries. They are largest in England, France and the US and smallest in Austria and Switzerland. Greece, Spain, and Sweden are now also in the low inequality group.

\section{Discussion}

If socio-economic health inequalities are to be taken serious as policy-relevant issues, indicators should be robust with respect to stratification variable. With this respect, the results presented in this paper are fairly mixed. Some countries such as the US, England or France are relatively unequal independent of the stratification variable, while Switzerland and Austria are always relatively equal. Others, such as Italy, show dramatic changes in their rank. Thus, researchers addressing cross-national differences health inequality should try to check the robustness of their results using different measures of socio-economic status before drawing policy conclusions.

Acknowledgements: This paper uses data from the early release 1 of SHARE 2004. This release is preliminary and may contain errors that will be corrected in later releases. The 
SHARE data collection has been primarily funded by the European Commission through the 5th framework programme (project QLK6-CT-2001-00360 in the thematic programme Quality of Life). Additional funding came from the US National Institute on Ageing (U01 AG09740-13S2, P01 AG005842, P01 AG08291, P30 AG12815, Y1-AG-4553-01 and OGHA 04-064). Data collection in Austria (through the Austrian Science Fund, FWF), Belgium (through the Belgian Science Policy Office) and Switzerland (through BBW/OFES/UFES) was nationally funded.

\section{References}

Börsch-Supan, A., A. Brugiavini, H. Jürges, J. Mackenbach, J. Siegrist J., and G. Weber (eds), 2005, Health, Ageing and Retirement in Europe - First Results from the Survey of Health, Ageing and Retirement in Europe. (MEA, Mannheim).

Jürges, H., 2007, True health vs. response styles: Exploring cross-country differences in selfreported health, Health Economics (forthcoming).

Juster, T. and R. Suzman, 1995, An overview of the Health and Retirement Study, Journal of Human Resources 30, S7-S56.

Kakwani, N., A. Wagstaff, and E. van Doorslaer, 1997, Socioeconomic inequalities in health: measurement, computation and statistical inference, Journal of Econometrics 77, 87-103

Marmot, M., J. Banks, R. Blundell, C. Lessof, J. Nazroo, 2003, Health, wealth and lifestyles of the older population in England: The English Longitudinal Study of Ageing. (Institute for Fiscal Studies, London). 
OECD, 1999, Classifying Educational Programmes. Manual for ISCED-97 Implementation in OECD Countries. 1999 edition. (OECD: Paris).

Wagstaff, A., E. van Doorslaer, and N. Watanabe, 2003, On the decomposing the causes of health sector inequalities with an application to malnutrition inequalities in Vietnam, Journal of Econometrics 112, 207-223.

WHO, 2000, The World health report 2000. Health systems: Improving performance. (WHO: Geneva). 
Table 1: Sizes of HRS, ELSA and SHARE working samples

\begin{tabular}{lrr}
\hline Country & $\mathrm{N}$ \\
\hline United States (HRS) & 10,830 & \\
England (ELSA) & 9,411 & \\
SHARE total & 17,891 & \\
Austria & & 1,652 \\
Germany & & 2,351 \\
Sweden & & 2,516 \\
Netherlands & 2,290 \\
Spain & 1,987 \\
Italy & 2,150 \\
France & & 1,360 \\
Denmark & & 1,290 \\
Greece & & 1,534 \\
Switzerland & & 761 \\
Total & & \\
\hline
\end{tabular}

Table 2: Health Gini and concentration indices (standard errors in brackets).

\begin{tabular}{|c|c|c|c|c|c|c|c|c|}
\hline \multirow[b]{2}{*}{ Country } & \multicolumn{2}{|c|}{ Pure health inequality } & \multicolumn{2}{|c|}{$\begin{array}{l}\text { Education-related } \\
\text { inequality in health }\end{array}$} & \multicolumn{2}{|c|}{$\begin{array}{l}\text { Income-related inequality } \\
\text { in health }\end{array}$} & \multicolumn{2}{|c|}{$\begin{array}{l}\text { Wealth-related inequality } \\
\text { in health }\end{array}$} \\
\hline & Gini coefficient & Rank & $\begin{array}{l}\text { Concentration } \\
\text { index }\end{array}$ & Rank & $\begin{array}{l}\text { Concentration } \\
\text { index }\end{array}$ & Rank & $\begin{array}{l}\text { Concentration } \\
\text { index }\end{array}$ & Rank \\
\hline Switzerland & $\begin{array}{l}0.0703 \\
{[0.0039]}\end{array}$ & 1 & $\begin{array}{l}0.0105 \\
{[0.0038]}\end{array}$ & 1 & $\begin{array}{l}-0.0038 \\
{[0.0034]}\end{array}$ & 1 & $\begin{array}{l}0.0124 \\
{[0.0033]}\end{array}$ & 2 \\
\hline Sweden & $\begin{array}{l}0.0791 \\
{[0.0023]}\end{array}$ & 2 & $\begin{array}{l}0.0130 \\
{[0.0020]}\end{array}$ & 5 & $\begin{array}{l}0.0133 \\
{[0.0020]}\end{array}$ & 9 & $\begin{array}{l}0.0177 \\
{[0.0021]}\end{array}$ & 5 \\
\hline Netherlands & $\begin{array}{l}0.0838 \\
{[0.0025]}\end{array}$ & 3 & $\begin{array}{l}0.0131 \\
{[0.0022]}\end{array}$ & 6 & $\begin{array}{l}0.0117 \\
{[0.0024]}\end{array}$ & 6 & $\begin{array}{l}0.0245 \\
{[0.0023]}\end{array}$ & 8 \\
\hline Denmark & $\begin{array}{l}0.0937 \\
{[0.0035]}\end{array}$ & 4 & $\begin{array}{l}0.0149 \\
{[0.0032]}\end{array}$ & 7 & $\begin{array}{l}0.0124 \\
{[0.0035]}\end{array}$ & 8 & $\begin{array}{l}0.0265 \\
{[0.0034]}\end{array}$ & 9 \\
\hline Germany & $\begin{array}{l}0.0948 \\
{[0.0027]}\end{array}$ & 5 & $\begin{array}{l}0.0118 \\
{[0.0024]}\end{array}$ & 3 & $\begin{array}{l}0.0142 \\
{[0.0024]}\end{array}$ & 10 & $\begin{array}{l}0.0236 \\
{[0.0025]}\end{array}$ & 7 \\
\hline Austria & $\begin{array}{l}0.0974 \\
{[0.0034]}\end{array}$ & 6 & $\begin{array}{l}0.0124 \\
{[0.0031]}\end{array}$ & 4 & $\begin{array}{l}0.0034 \\
{[0.0031]}\end{array}$ & 2 & $\begin{array}{l}0.0074 \\
{[0.0031]}\end{array}$ & 1 \\
\hline France & $\begin{array}{l}0.0991 \\
{[0.0038]}\end{array}$ & 7 & $\begin{array}{l}0.0218 \\
{[0.0031]}\end{array}$ & 11 & $\begin{array}{l}0.0181 \\
{[0.0037]}\end{array}$ & 11 & $\begin{array}{l}0.0298 \\
{[0.0037]}\end{array}$ & 10 \\
\hline Greece & $\begin{array}{l}0.1034 \\
{[0.0035]}\end{array}$ & 8 & $\begin{array}{l}0.0118 \\
{[0.0028]}\end{array}$ & 2 & $\begin{array}{l}0.0071 \\
{[0.0035]}\end{array}$ & 4 & $\begin{array}{l}0.0154 \\
{[0.0034]}\end{array}$ & 3 \\
\hline Italy & $\begin{array}{l}0.1037 \\
{[0.0030]}\end{array}$ & 9 & $\begin{array}{l}0.0212 \\
{[0.0023]}\end{array}$ & 10 & $\begin{array}{l}0.0060 \\
{[0.0025]}\end{array}$ & 3 & $\begin{array}{l}0.0214 \\
{[0.0029]}\end{array}$ & 6 \\
\hline United States & $\begin{array}{l}0.1105 \\
{[0.0013]}\end{array}$ & 10 & $\begin{array}{l}0.0237 \\
{[0.0012]}\end{array}$ & 12 & $\begin{array}{l}0.0347 \\
{[0.0013]}\end{array}$ & 12 & $\begin{array}{l}0.0361 \\
{[0.0013]}\end{array}$ & 12 \\
\hline Spain & $\begin{array}{l}0.1117 \\
{[0.0033]}\end{array}$ & 11 & $\begin{array}{l}0.0184 \\
{[0.0023]}\end{array}$ & 8 & $\begin{array}{l}0.0075 \\
{[0.0030]}\end{array}$ & 5 & $\begin{array}{l}0.0157 \\
{[0.0031]}\end{array}$ & 4 \\
\hline England & $\begin{array}{l}0.1131 \\
{[0.0015]}\end{array}$ & 12 & $\begin{array}{l}0.0197 \\
{[0.0015]}\end{array}$ & 9 & $\begin{array}{l}0.0121 \\
{[0.0013]}\end{array}$ & 7 & $\begin{array}{l}0.0315 \\
{[0.0014]}\end{array}$ & 11 \\
\hline
\end{tabular}


Table 3 Classification of countries, by size of health inequalities

\begin{tabular}{|c|c|c|c|}
\hline \multirow[b]{2}{*}{$\begin{array}{l}\text { Individuals are } \\
\text { ranked by: }\end{array}$} & \multicolumn{3}{|c|}{ Age-sex standardized inequality in health is significantly...a) } \\
\hline & ... smaller than average & ... not different from average & ... larger than average \\
\hline Health & Netherlands, Sweden, Switzerland & $\begin{array}{l}\text { Austria, Denmark, France, } \\
\text { Germany }\end{array}$ & England, Greece ,Italy, Spain, US \\
\hline Education & Germany & $\begin{array}{l}\text { Austria, Switzerland, Spain, } \\
\text { Greece, Sweden, Netherlands, } \\
\text { Denmark }\end{array}$ & England, France, Italy, US, \\
\hline Income & Austria, Italy, Switzerland & $\begin{array}{l}\text { Spain, Germany, Greece, } \\
\text { Sweden, Netherlands, Denmark, } \\
\text { England }\end{array}$ & France, US \\
\hline Wealth & $\begin{array}{l}\text { Austria, Greece, Spain, Sweden, } \\
\text { Switzerland }\end{array}$ & $\begin{array}{l}\text { Germany, Denmark, Italy, } \\
\text { Netherlands }\end{array}$ & England, France, US \\
\hline
\end{tabular}

a) at the $90 \%$ level 


\section{Discussion Paper Series}

Mannheim Research Institute for the Economics of Aging Universität Mannheim

To order copies, please direct your request to the author of the title in question.

\begin{tabular}{|c|c|c|c|}
\hline Nr. & Autoren & Titel & Jahr \\
\hline $128-07$ & Axel Börsch-Supan & $\begin{array}{l}\text { European welfare state regimes and their } \\
\text { generosity towards the elderly }\end{array}$ & 07 \\
\hline $129-07$ & $\begin{array}{l}\text { Axel Börsch-Supan } \\
\text { Alexander Ludwig } \\
\text { Mathias Sommer }\end{array}$ & Aging and Asset Prices & 07 \\
\hline $130-07$ & Axel Börsch-Supan & $\begin{array}{l}\text { Nachfrageseitiger Wettbewerb im } \\
\text { Gesundheitswesen }\end{array}$ & 07 \\
\hline $131-07$ & $\begin{array}{l}\text { Florian Heiss, Axel } \\
\text { Börsch-Supan, Michael } \\
\text { Hurd, David Wise }\end{array}$ & $\begin{array}{l}\text { Pathways to Disability: Predicting Health } \\
\text { Trajectories }\end{array}$ & 07 \\
\hline $132-07$ & Axel Börsch-Supan & Rational Pension Reform & 07 \\
\hline $133-07$ & Axel Börsch-Supan & Über selbststabilisierende Rentensysteme & 07 \\
\hline $134-07$ & $\begin{array}{l}\text { Axel Börsch-Supan, } \\
\text { Hendrik Jürges }\end{array}$ & $\begin{array}{l}\text { Early Retirement, Social Security and Well- } \\
\text { Being in Germany }\end{array}$ & 07 \\
\hline $135-07$ & Axel Börsch-Supan & Work Disability, Health, and Incentive Effects & 07 \\
\hline $136-07$ & $\begin{array}{l}\text { Axel Börsch-Supan, } \\
\text { Anette Reil-Held, } \\
\text { Daniel Schunk }\end{array}$ & $\begin{array}{l}\text { The savings behaviour of German households: } \\
\text { First Experiences with state promoted private } \\
\text { pensions }\end{array}$ & 07 \\
\hline $137-07$ & $\begin{array}{l}\text { Hendrik Jürges, } \\
\text { Mauricio Avendano, } \\
\text { Johan Mackenbach }\end{array}$ & $\begin{array}{l}\text { How comparable are different measures of self- } \\
\text { rated health? Evidence from five European } \\
\text { countries }\end{array}$ & 07 \\
\hline $138-07$ & $\begin{array}{l}\text { Hendrik Jürges, } \\
\text { Kerstion Schneider }\end{array}$ & $\begin{array}{l}\text { What can go wrong will go wrong: Birthday } \\
\text { effects and early tracking in the German school } \\
\text { system }\end{array}$ & 07 \\
\hline $139-07$ & Hendrik Jürges & $\begin{array}{l}\text { Does ill health affect savings intentions? } \\
\text { Evidence from SHARE }\end{array}$ & 07 \\
\hline $140-07$ & Hendrik Jürges & $\begin{array}{l}\text { Health inequalities by education, income, and } \\
\text { wealth: a comparison of } 11 \text { European countries } \\
\text { and the US }\end{array}$ & 07 \\
\hline
\end{tabular}

